\title{
展望
}

\section{フロスティック視知覚発達テストおよびフロスティック 視知覚発達プログラムの開題点}

\author{
角本 順 次 \\ (鳥敢大器教育器)
}

フロスティック視知覚発達テストがわが国でもさかんに用いられるよ5になって来た。このテストは1958年に フロスティックらの手で考案されて以来改訂を重致て、アメリカではいまや「学校や臨休の場でしばしば無差別 に用いられている」39)といわれるほどに普及している。さらにこのテストは、これにより発見された視知覚機能

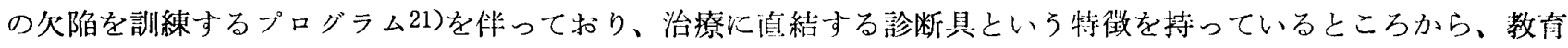
現場に颃いて非常にうけ入れやすいものとなっている。

しかしながら、このテストおよびプログラムには理論的、奏用的两面に拈ける問題点もあり、それらを十分認 識した上での適切な使用が必要である。ここではそれらを検討した諸研究を概観し、閣題点を整理して今後に資 したいと考える。

\section{妥当性に関する問題}

フロスティック・テストの開鼠点を指摘した論文の多 くが、このテストの囚子分析的砄究にもとずくものであ り、このテストの妥当性ないし持效性に闺する理諭的な 閣題を提起している。

このテストは、視覚一運動共応、戍一地阘係、形の恒労 性、空間位置、空閣䦥倸とい5「学桨に特に閔倸の深い 視知覚諸過程」19)に対応する 5 橭のサブテストから成っ て拈り、フロスティックらによって、これらのサブテス 卜はある程度相互に独江したものであるとされている。 ただフロスティックら䏟はこのテストについて因于分 析的研究を実施して扔らず、この点については他の人た ちの研究を参照されたいとして2稖の論文を紹介してい るのみである。そのひとつは Corah 抢上び Powell 14) によるものであるが、フロスティックら萩によって紹 介されたこの研究が、笑は上記 5 個のサブテストの独立 性学支持していないのである。

このふたりは、精神薄弱児を除く保育園男尖児望計40 人に刘し、知能テスト、フロスティック・テスト、重複 四形テスト、形態恒常性テストを実施した。そしてフロ スティック・テストからは 5 個のサブテストの得点と知
党指数PQをもって 6 碑の变数とし、他のテスト結果 と、さらに被験者の年解、性别をる加えて合部11個の变 数につ是内部相閶を求め、主成分法に上り因子分析を試 みた。その結果彼らは、第1の因子が知能テスト拉よび フロスティック・テストの「視党一運動期応」「空閒位 置」「空間関係」のサブテストに比較的商い傎荷を持つ ことから、これを一般知能因子とし、次に被験者の年龄 とフロスティック・テストの「視覚一運動共応」「「|为|-地 閶係」「形の恒常性」のサブテストに適度の值蒜を持つ 第2の因子を㓡喾発達因子とした。こ5してふたつの主 要な因子を見怙し、さらにこのテストから得られる刘営 指数は知觉発避を测定与るのによい人度であるとしたも のの、反面、個々のサブテストの得点は必らずしも信頼 できるものでなく、これ沈もとずいて判断を下すことに は疑間があると結諭した。つまり彼らは、このテスト が、フロスティックのい5よ5に、5 個の此較的独立し た視知覚下位機能を测定し得るものだという主張に疑問 を投げかけたのである。

フロスティックら自身がこの論文を紹介したあとめ、 いく人もの人たちによってこのテストの《凷分析的矵杂 が行われた。

Allen 1)は、10才から16才までの軽度精神薄弱児 36 人 
にフロスティック・テストを実施し、主成分治により、 冬サブテストに高い份荷を持つ単一の因子を抽出した。 さきのCorah 拉よび Powell の研究結果（2因子）と 翼なることについて彼は、その対象坚が各下位機能に拉 いて一様に低い能力を持つからだと説明している。

Olson35)は、このテストのサブテストが、果してフロ スティックのいうように個々の独立した知覚能力を測定 し得るものかど5かを阿5ため、5 篇の因子分析的研究 論文を検討している。そして Corah と Powell の研究 は調查対象児の数が少なすぎるので価值が泛しいときめ つけ、他の 4 篇を通じて得た結論を次の上5にま之め た。ーフロスティック・テストの 5 個のサブテストには 1 個の共通する知覚機能が含まれるにすぎず、したがっ てそれらは個別の能力を测定するものだとは考光難い。 フロスティック・テストの内容的妥当性には重大な疑閵 がある一。

その後もこのテストについてほぼ同様の研究が続い た。Boyd と Randle 8) は平均知能の小学 1 年生児童 94 人にこのテストを実施し、主成分法により、5 個のサブ テストに共に高い負荷を持つ1. 個の因子を得た。そして Olson と同しくくこのテストは本質的には 1 個の視知 敩因子を測定しているのみで、個別の視知覚諸能力を示 すむのとはいえず、内容的妥当性には大きな疑問がある とした。ただ彼らも、このテストの $\mathrm{P} Q$ 亿は意義があ るとして抢り、この点はさきの Corah 抢よび Powell と同様である。

Smith と Marx39) は、精神薄弱児を除く 5 才から 10 才までの児童46人に、フロスティック・テスト、知能デ ス卜、読及能力テストを実施して、やはり、知覚構成 perceptual organization ともいらべきひとつの因子を 見出した。

Chissom と Thomas10)が調ベたところでは、フロス ティック・テストに関する因子分析的研究 12 篇中 10 篇 が、分散の約 $50 \%$ を占める 1 個の因子を得ているとい 5 。彼ら自身40)が38人の児童 (平均年跲 5 才 8 力月) 飞 ついて行った研究に拈いても、因子行列を值交回転した 主成分法汇上り、分散の $48 \%$ を占める 1 個の因子が得ら れたとして、他の多くの研究と一致した見方をとってい る。

このよ5に、フロスティック・テストが単に 1 個の因 子にかかわるのみであるとする報告が多いのに対して、 Becker と Sabatino 4)は 3 因子説をとっている。彼ら は、ささの Boyd と Randle の研究がフロスティック・ テストのサブテストのみを用いて他のものを用いなかっ たことに限界があったと批判し、ひとつの主成分が抽出
されるには、相!机滵接な䦥速を持つ少くともふたつの テストが必要なのだから、フロスティック・テストの 5 個のサブテストが因子的に分解され得るかどうかを決定 するには、同様の行動を測定する他のテストを加えねば ならないと主張する。さらに Olson が検討した諸論文 は、語い、視知覚、視覚一運動、知能、学力、といった 多様なテストを用いているが、自分たちの研究はこれら と異なり、フロスティック・テストの因子構造に閣連す る特定の行動のみを用いたと述べている。彼らが用いた のは、I Q，フロスティック・テスト，ベンダー・テスト， 視喾単語异別テストであり、これらを精神薄弱児を除く 154 人の幼稚園児に実施し、主成分法に上り因子分析を 行った。その結果彼らは、「視覚一運動共応」および「空 間関倸」のサブテストが視覚運動因子に、「図一地関係」 および「形の恒常性」のサブテストが、さきのCorahPowell の報告と同じく图一地因子に、それぞれクラス ターして括り、「空間位置」のサブテストは単独で視覚 於別因子に負荷を持つとして、これらの 3 因子を等げて いる。

続けて彼らはこう述べている。一空間位置のサブテス トが第 3 の因子（視覚升別）に高い負荷を持ち、この因 子が運動的共応を要する他の 4 個のサブテストにクラス ターしていないことから、空間位置のサブテストのみが 预測的妥当性を持つとい方るか子知れない。フロスティ ック・テストが果して視知覚と視覚一運動とをどれだけ 区別しているかが問題で、空間位置のサブテストのみ が、運動に負荷を持たない、唯一純粋の視知覚种别のテ ストである一。

たしかに、フロスティック・テストの 5 個のサブテス トの5ち4個までは、鉛筆で線を画くという、視覚一運 動系を混入している。少なくともフロスティック自身 は、ベンダー、ベントン、グッドイナフその他のテスト が図形やパターンを再生する作業を含んでいて、知覚の みを調べるものでない点が不十分であるとし22)、このテ ストの作成にあたっては知喾一運動系の混入を避けるよ うにした19）と述べて扮り、事実、第1サブテスト（視 覚一運動共応）は別として、第 $2 、$ 第 3 、第 5 サブテス トでは線画さの多少の不正確さは重視しないことになっ ている。とはい5ものの、線画きとい5運動活動を排除 与る点では Becker らのいうょ5に不十分で、彼らの当 初の意図が果されたとはいい難い。このことは、「弁別、 操作、模写を含む課題での反応のゆがみは、これまで知 覚の欠宿によると解秎されて来たが、この場合、模写だ けができない子ぞもと、同定すらできない子どもとは知 覚の上で異なるものだ（Bortner)」7）とする意見にてら 
して重要な点である。このような考えに占って、知覚と 知覚一運動とを分けて报からべきだとし、升别や選択の みによる視知覚テストを考案する向きがある(Cutler,15) Friedrich, 17) Johnson 28)) のは理解できるところであ る。

このように、フロスティック・テストの5 佔のサブテ ストが、それぞれ対沁する 5 個の独立した視知覚技能を 測定するものでないとする報告、それにこのテストが視 知覚テストといいながら、視知覚と運動との複合機能を 测定しているという見方を合わせ考光るとき、このテス トの妥当性に関寸る疑間が生じて米るのも無理から奴と ころであろう。

\section{学カとの関係について}

フロスティックは、このテストに打ける低い成績が読 み書きの欠陷と深い関係を持つ19）としているが、この ことについては场支持的、否定的な研究結果が多く 寄せられている。

Hammill 525) 怯、下層地区、住学幼稚園児上小学 1 年生児童計 162 人に対し、フロスティック・テスト，学 カテスト，学業レディネス・テスト，知能テストを実施し て、フロスティック・テストの $\mathrm{P} \mathrm{Q}$ は知能や学力との間 に高い相関を持ら、このテストの妥当性は高いものの、 いくつかの因子分析的研究が、 5 個のサブテストが単 に1個の知覚因子を测定しているに過ぎないとしている ことから、このテストの妥当性は未だ十分に帮証されて いないと絬論した。彼らはこの中で、フロスティック・ テストの予測具としての有効性にかかわる妥当性の問题 は全く未解決であり、今後は、例之ば「形の恒常性」の サブテストで少っている幼稚園児が果してのちに単話 の認知の欠陷を示するのか、あるいはまた妙稚園時代の 「視敩一運動共応」のサブテスト成蹟が小管 2 年生になっ たとさの書さ才の技能を玵しく予测し得るか、といった 砸兊が必要であるとした。

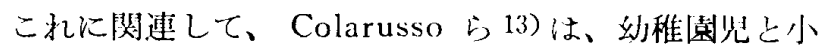
䇣 1 年生の児童計125人にフロスティック・テストを実施 し、2 年後同じ児童に学力検查を尖施して、フロスティ ック・テストの総得点が読みの学力の予测具として不邀 当であり、また 5 個のサブテスト結果も後年の等力とは 関係がなかったと報告している。さきに举げた Smith と Marx 39) の研究仙よれば、フロスティック・テスト の $\mathrm{PQ}$ も各サブテストの得点もともに読みの学力との間 に䦌連がなかったという。

DuBois と Brown16) は、入学後 8 カ月たった小学 1 年生児童 163 人に対し、フロスティック・テストと読み
のテスト（語い打よび理解）を実施し、このテストが䛨 みの学力に関連する特定の技能を湘定しているとは洘え られないと述べている。

Chissom 511)は、平均 5 才 8 力月の幼稚園児 39 人に フロスティック・テストその他の視临一運動テスト，学》 テスト，それに教師の評定を行い、その結果、フロステ イック・テストの総得点は学力と大きな関係があり、学 力の予测具としてすぐれているとしている。

わが国では毛利ら34)がこのテストと就みの学力との 阙係を調べ、精神薄弱児（17人、MA 4-8才）では 「視覚一運動共応」「図一地関係」「空間位置」のサブテ ストと読みとの間に有意な関係が認められ、普通先（22 人、小学 1 年生) では「図一地関係」「形の恒常性」」「空 阔位置」「空間関係」の+ブテストと読みとの間に有 意な関係が認められたと、支持的な結果を発表してい る。ただし、刘象児の人数が少いこと、精神薄弱児の $\mathrm{M}$ Aが分散していることから、こ机を予備的研究であると 断っている。

Black 6)は、フロスティック・テストの $\mathrm{PQ}$ と学力と の間には、小学校低学年児に㨟いては高い相関が認めら れるが、各サブテストと学力との相関については明らか でないのが現状であると述べ、自らは、性、年秢、知能 (I Q85以1:)、家庭の社会経済的地位をマッチさせた 30 組の児童について調查した。そして被験睍たちをフロス ティック・テストのト位群と下位群に分け、峃)（読み,

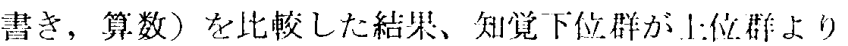
も学打で少るということはなかったと報告している。こ こで彼は、その被験児たちが小学 1 年生から 4 年生まで の、平妇年令 8 才の睍童たちなので、この年令では視知

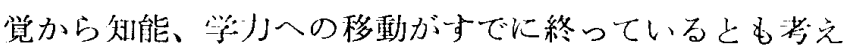
られるとつけ扣えているが、それにしても、学望障害照 の評価と治療に括いて視知覚の役割が過度に重視されて いると述べているのが注目される。

Mycrs \& Hammill 33)は、このテストと墩及の㑷川 ないしレディネスとの関係について、諸研究の結果を要 䄪して「フロスティック・テストは、子どもが 1 年生の 上きの読みのレディネスを予测しは寸るが、2年生、3

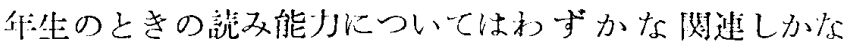
いよとている。

Allington ら2)によれば、読みが劣るのは、フロスティ ックや他の人たちがいうように知営に欠陌があるからで はなく、言語の伀達・連合によるのであり、したがって梓 みの劣る罗童に対して視知覚の訓練を実施することも疑 問であるという。 


\section{視知覚訓練の効果について}

ここで、フロスティック視知筧発達プログラム21）を用 いた視知覚ないし視覚一運動の訓練が、フロスティック18) のいらよ5に、読みを含む学力の向上をもたらし得るか ぞうかを調べた研究をいくつか眺めてみることにする。

Rosen37)は、637人もの小学 1 年生児童を 2 群に分 け、実験群には1日30分つう、29日間にわたって、フ ロスティック・プログラムを用いた知覚訓練を小集団で 実施し、その前後に括ける読及能ナテストなどの成績を 比較した。その結果、実験群ではたしかに知覚は向上し たものの、読みは向上しなかったと報告している。この 中で彼は、知覚の訓練よりも読及の指導の方が重要では ないかと述べているが、これに関連して Cohen 12) る、 読みの力をつけるには、知覚ごっこなどやめて読みとの ものを指導する方がよいと批判して括り、Rosen と同 様の考竞をとている。

Anderson と Stern3)は、フロスティック・テストで $P Q 90$ 以下の、6-8 才の児童30人に、毎週 5 日つ’つ、 16週間、1 回30分の、フロスティック・プログラムによ る訓練を実施し、やはり読及の学力向上が得られなかっ たことを報告している。

Buckland とBalow 9) は、教師の評定と学力テストで 読みの劣る小学 1 年生児童 166 人を選び出し、これを 2 群に分けて、実験群にはフロスティック・プログラムを 1 日 15 分間、40日間にわたって、3-7人の小グループ で実施した。そして実験の前と後に拈けるフロスティッ ク・テストおよび読みレディネス・テストの成績を比較 したところ、知覚に招いても読みに批いても、両群間に 有意な差は認められず、むしろ、知覚も読みのレディネ スもともに劣る児童には、括話を聞かせたり、これにつ いて話し合ったりさせる方が読みの向上には有効であっ たと報告している。

Bieger 5)は、小学 $2-3$ 年生の、フロスティック・テ ストで $\mathrm{P} Q 85$ 以下の、かつ読みの劣る児童48人を 2 群に 分け、実験群にはフロスティック・プログラムなどによ る視知覚訓綀を 1 時間づつ、週 2 回、7 カ月間行ったが、 その結果、これによって知覚の向上は見られたが読みの 学力は向上を見なかったとしている。

Martin 31) は諸研究を展望して、フロスティック・プ ログラムが視知覚や読みの学力を向上させるのには役立 たないとし、またこのプログラムが伸ばそうとしている 視知覚諸領域と、読みを構成する諸技能との間に大さな 関係がないことを示唆している。

この点について Hammill 20)は、広範な展望に立って
批判的な見解を明らかにした。それによると、フロステ イックのものを含めたいくつもの視知覚訓練プログラム は、視知覚機能が学習過程の重要な要因だとする考之に もとずいているのだが、彼が調查した関係論文42篇中、 手続きその他で検討に価するるのを 12 篇選んで調べたと ころ、8 篇が視知覚と読みとの間に有意な関係を認めて 扔らず、残り 4 篇は、被験者が 25 人以下と少なかったり、 相関が 0.3-0.49とさして高くないものであった。さら に視覚一運動訓練によって読みに向上が見られたかどう かについてみるに、関係論文 25 篇中 21 篇は否定的な結果 であり、肯定的結果を得たとする 4 篇は手続や結論に問 題のあるものばかりであった。最後に彼は視知覚過程そ のものが訓練可能なものなのかと問い、やはりいくつか の報告から否定的な結論をひき出している。そして彼は 以下の上うな辛らつな文章でその意見をしめくくってい る。

一今や至るところ 視覚一運動訓練と称する方法・器材 の氾濫があり、また、日く読みの向上、日くレディネス の補強、日く視知覚発達の促進といったブログラムの扗 大を無批判に有難がる教師・心理学者たちのコーラスが ある。ところが、今のところ諸研究の結果は逆の方向を 示して打り、視知覚訓練は学力の向上に役立たず、視知 覚そのものが、少くとも既存のプログラムでは、訓練で きないのである一。

このような Hammill の批判は、学業におくれのある 児童について、その診断と治療の上で視知覚の役割を過 大に評価し、他の心理機能の役割や指導技術の重要性を 相対的に軽視する傾向に対して向けられたものとる解せ られるのである。また Sabatino ら 38) む、視知覚は、 読みのレディネスにとって重要ではあるが、読みに必要 ないくつもの変数の中のひとつに過ぎないとして、他に も例えば語いや聴知覚も重要であろう、と妥当な意見を 明らかにしている。この点に関連して興味をひくのは Halliwell と Solan24)による報告である。

彼らは 1 年生児童 105 人を学力、性別でマッチさせた 3 群に分け、第 1 群にはフロスティック・プログラムを含 めた一連の知覚および知覚一運動訓練、それに通常の読 みのプログラムを、第 2 群には補足的な読みの指導と通 常の読みのブログラムを実施し、第 3 群はコントロール 群とした。訓練・指導は45分間づつ週に 2 回、7カ月間 実施し、第 1 群の児童が読みの能力に扣いて他の群上り も高くなったことを認めた。ここで彼らは、多くの研究 が、知覚訓練は読みの向上に役立たなかったとする結果 に終ったのに対し、自分たちが肯定的な結果を得た理由 として、実施期間が他の研究のそれょりも長かったこ 
と、訓練・指導がより総合的なものであったこと、児童 を小集団で訓練したこと、十分に研修を積んだ職員によ って訓練を行ったこと、などを挙げている。

\section{実用上の問题点}

以上のこととは別に、フロスティック・テストには実 用的な面で奇妙な問題がある。このテストの適用年齡は 4 才以上 8 才末満となっているが、8 才以上の者に対し ても、手引 20)に示された換算表により、粗点を知覚年 齢に換算し、知覚指数 $\mathrm{PQ}$ ○算出できるようになってい る。しかしこの手続によって 8 才以上の児童の知覚レべ ルを調べようとするときに問題が生じるのである。今か りに 8 才 0 カ月の児童 2 人にこのテストを実施し、1 1 人 は 5 個のサブテストすべてに打いて粗点で満点をとった とすると、手引にしたがってそれぞれ頭打ちの評価点10 点が与えられる。そして評価点合計は 50 点で、 $\mathrm{P} Q$ Q 100 といらことになる。る51 人の児童は、すべてのサ ブテストで満点より 1 点だけ少い粗点をとったとき、評 価点合計は53、P Q 106 となる。かくして、同年踚の 児童 2 人の5ち、より低い作業成績（粗点）の者が、よ り高いP Qを与えられるといら不合理が生じる。このこ とは Smith ら39)によってすでに指摘されているが、わ が国でも、使用した現場から不審にうけとられていると ころである。

さらに、粗点を知覚年龄に換算する換算表についてこ まかい点を挙げれば、第4サブテストに括いて粗点 7 は $7 才 0$ カ月の知覚年令に達しているとされるが、これが わずか 1 点高い粗点 8 になると8才9カ月の知覚年齢に達 しているものとされ、わずか 1 粗点の差が知覚年秢で 1 年9カ月の差になるといらステップの粗さが見られる。 標準化のさいにこのことは処理されているとはいうもの の、理論的には鬼も角、実用的には疑問なしとしない。

また、このテストの標準化にあたって用いられたサン プルが注とんぞ中産階級の白人児童であることをフロス ティック自身も認めて打り、Cruickshank24)もこの点を フロスティック・テストの泣きどころだとしている。一 方、ニューヨーク市内の下層地区児童にこのテストを実 施したところ、P $\mathrm{Q}$ 平均の高い方から順に中国系、白人 系、プエルトリコ系、そして黒人系といら結果になった という報告 12）もある。ひるがえってわが 国の児童は、 幼少の頃から生活習慣や遊びの中で 視覚一運動活動を豊 富に経験している（ハシ，ヒモ，オリガミ，アヤトリ， オ八ジキ等々）ところから一般に器用であり、加えて親 の教育的配慮もあつく、さまざまな玩具、文具を与えら れているから、このテストに打ける成績はアメリカ人児
童の標準よりも高いことが想像される。現に、川合ら29) が 5 才児 357 人について明らかにしたところによれば、 これら日本人児童はアメリカ人児童の標準に比較して、 第 2 サブテストを除くすべてのサブテストで有意に高い 成績を示している。（第 2 サブテストでも日本人児童の 方が高いが、有意差はない。）現在わが国で診断用に実 施されているフロスティック・テストでは、採点にあた ってアメリカの換算表をそのまま用いているが、これは 正しい使用法ではない。さきの川合らによる日本版標準 化の試みが早期に完成することを期待したい。近くフロ スティック・テストの日本版翻訳 27) が出される模様で あるが、これが手引の単なる翻訳であるか、日本版とし て標準化がなされたものであるか、現時点で筆者は知ら ない。

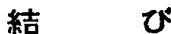

以上見て来たように、フロスティック・テストにはい ろいろな問題点がある。しかしながら完全なテストとい ろものは望むべくもない。そこで Rohracher 36) もい5 よ5に「医学の分野です心理診断の面でも、被信賴性 （妥当性)のはっきりしい猃断的手続は多いが、それら で得た結果を、他の方法での成績と組み合わせて利用す る」というやり方がとられることになる。フロスティッ ク・テストの場合も同様である。もちろん他のテストを 併用することは䛦断上重要であるが、フロスティッ ク 22）わい5上5に、子どもが教室で示す学習上の特徵 も、教師にとって、視知覚障害の指標となり得るのであ る。ただ、Cruickshank23)の言を借りれば、「いくつか の因子分析的研究からは、サブテストの独立性が問題に なっており、この点は未解決であるから、このテストに よって子どもの視知覚の諸側面を調べよ 5 とするさいに は十分な注意が必要である。」当面は、すでに見て来た ごとく、PQに対しては支持的な見方も多いところから、 これを「全過程を総括するものと考兄 (McIntosh)32)」、 サブテストの成績よりる、総合的な成績としての $\mathrm{P} Q$ を、視知覚機能の診断上重視するという用い方がよいと 考えられる。

読み書きなどの学力とフロスティック・テストとの関 係については、学力というるのを知覚や知覚一運動とい った基礎的心理機能のほか、学習に関係あるさまざまな 心理機能、それに指導法の有機的結合の結果であると考 えるべさで、視知覚の役割を過大視するあまり、このテ ストの成績と学力との直接的関係をこれ以上追求するこ とは生産的でない。むしろ筆者は、この両者の関係を過 大評価して、知覚訓練が、期待したような学力向上をも 
たらさなかったときに、反動的に視知覚機能の役割を軽 視することになるのを恐れる。

ここから、フロスティック・プログラムを含めて、い ろいろな視知覚ないし視覚一運動の訓練を実施すること の、学業上の効用もまた冷静に考えられるべきである。 知覚の訓練はたしかに知覚技能を向上させるであろ が、これが直らに学力の向上につながるといった期待は あまりにも楽镜的といわ稀ばならない。ただ、普通児で あれ、障害児であれ、幼览期に括いて知覚や知覚運動の ような基礎的心理機能を十分に獲得させることは、その 後の発達にとって重要であろ弓。現在、養護学校や特殊 学級に打いて「養護・訓練」の中で行われているこれら の機能の訓練は、やや遅い時期にあたって招り、時間的 にも十分とはいえない例が多い。かりにこれらの点で訓 練が適切に実施されたとしても、その成果がいか汇学業 に転移して行くのか、いかにしてその効果的な転移を教 育の中で用意寸ればょいのか、といろ点ではさらに研究 が必要である。たしかに、例えば Luria 30)のい5ょ5 に、空間定位の過程は数計算や論理一文法の過程との間 に共通するものがあろらが、このような知識を指導上ど 5活用するかについては今後の教育的実験（実践）にま つところが大きい。フロスティックの業積は、このよ5 な点の重要性をあらためて提起したことに、その価值が あるといえるのではなからうか。（1976.12.2・受）

\section{文献}

1) Allen, R. M. (1968): Factor Analysis of the Developmental Test of Visual Perception Performance of Educable Mental Retardates. Percept. Mot. Skills, 26, 257-258.

2) Allington, R. L., Gormley, K., \& Trux, S. (1976) : Poor and Normal Readers Achievement on Visual Tasks involving High Frequency, Low Discriminability Words.

J. Learn. Dis., 9, 34-38.

3) Anderson, D. \& Stern, D. (1972): The Re. lative Effects of the Frostig Program, Corrective Reading Instruction, and Attention upon the Reading Skills of Corrective Readers with Visual Perceptual Deficiencies. J. School Psychol., 10, 387-395.

4) Becker, J. T. \& Sabatino, D. A. (1973): Frostig Revisited. J. Learn. Dis., 6, 180-184.

5) Bieger, E. (1974): Effectiveness of Visual Perceptual Training on Reading Skills of
Non-Readers: An Experimental Study. Percept. Mot. Skills, 38, 1147-1153.

6) Black, F. W.: (1974): Achievement Test Performance of High and Low Perceiving Learning Disabled Children. J. Learn. Dis., 7, 178-182.

7) Bortner, M.: Evaluation of Psychological Deficit. in Bortner, M. ed. (1968), Evaluation and Education of Children with Brain Damage. Thomas.

8) Boyd, L. \& Randle, K. (1970) : Factor Analysis of the Frostig Developmental Test of Visual Perception. J. Learn. Dis., 3, 253-255.

9) Buckland, P. \& Balow, B. (1973): Effect of Visual Training on Reading Achievement. Exceptional Children, 39, 299-304.

10) Chissom, B. S. \& Thomas, J. R. (1971) : Comparison of Factor Structures for the Frostig Developmental Test of Visual Perception. Percept. Mot. Skills, 33, 1015-1019.

11) Chissom, B. S., Thomas, J. R., \& Collins, D. G. (1974) : Relationships among Perceptual-Motor Measures and their Correlations with Academic Readiness for Preschool Children. Percept. Mot. Skills, 39, 467-473.

12) Cohen, S. A. (1969) : Studies in Visual Perception and Reading in Disadvantaged Children. J. Learn. Dis., 2, 498-503.

13) Colarusso, R. P., Martin, H., \& Hartung, J. (1975) : Specific Visual Perceptual Skills as Long-Term Predictors of Academic Success. J. Learn. Dis., 8, 651-655.

14) Corah, N. L. \& Powell, B. J. (1963):A Factor Analytic Study of the Frostig Developmental Test of Visual Perception.

Percept. Mot. Skills, 16, 59-63.

15) Cutler, C. M., Cicirelli, V. G., \& Hirshoren, A. (1973) : Comparison of Discrimination and Reproduction Tests of Children's Perception. Percept. Mot. Skills, 37, 163-166.

16) DuBois, N. F. \& Brown, F. L. (1973): Selected Relationships between Frostig Scores and Reading Achievement in a 
First Grade Population. Percept. Mot. Skills, 37, 515-519.

17) Friedrich, D., Fuller, G. B., \& Hawkins, W. F. (1968) : Relationship between Perception (Input) and Execution (Output). Percept. Mot. Skills, 29, 923-934.

18) Frostig, M., Lefever, D. W., \& Whittlesey, J. R. B. (1961) : A Developmental Test of Visual Perception for Evaluating Normal and Neurologically Handicapped Children. Percept. Mot. Skills, 12, 383-394.

19) Frostig, M., Maslow, P., Lefever, W., \& Whittlesey, J. R. B. (1964) : The Marianne Frostig Developmental Test of Visual Perception. 1963 Standardization. Cosulting Psychologists Press.

20) Frostig, M. (1966) : Administration and Scoring Manual for the Marianne Frostig Developmental Test of Visual Perception. Revised, 1966. Consulting Psychologists Press.

21) Frostig, M. \& Horne, D. (1973) : Frostig Program for the Development of Visual Perception. Revised Edition. Follett.

22) Frostig, M. \& Maslow, P. (1973): Learning Problems in the Classroom. Grune.

23) Hallahan, D. P. \& Cruickshank, W. M. (1973) : Psychoeducational Foundations of Learning Disabilities. Prentice-Hall.

24) Halliwell, J. W. \& Solan, H. A. (1972): The Effects of a Supplemental Perceptual Training Program on Reading Achievement. Exceptional Children, 38, 613-621.

25) Hammill, D., Goodman, L., \& Wiederholt, J. R. (1971) : Use of the Frostig DTVP with Economically Disadvantaged Children. J. School Pschol., 9, 430-435.

26) Hammill, D. (1972): Training Visual Perceptual Processes. J. Learn. Dis., 5, 552-559.

27）飯鉢和子，鈴木陽子，茂木茂八（1977年日本版 翻訳発行予定)：フロスティッグ視知覚発達众 查. 日本文化科学社.

28) Johnson, D. L. A., Brekke, B., \& Follman, D. E. (1976) : Appropriateness of the MotorFree Visual Perception Test When Used with Trainable Mentally Retarded. Percept. Mot. Skills, 43, 1346.

29）川合尚汪か (1974)：Frostig 視知覚発達テス トの研究 第 1 報 一標準化の試及(1)一, 日本 心理学会第 38 回大会発琶諭文 集，1974，552553.

30) Luria，A．R．松野豐訳「人間の脸と心理過程」 命等臯房，昭51。

31) Martin, J. C. (1973) : Effects of Visual Per. ceptual Training on Visual Perceptual Skills and Reading Achievement. Percopt. Mot. Skilis, 37, 564 .

32) McIntosh, D. K. \& Dunn, L. M. (1973) : Children with Major Specific Learning Disabilities. in Dunn, L. M. ed. : Exceptional Children in the Schools. Holt, Reinhart and Winston.

33) Myers, P. I. \& Hammill, D. (1969): Methods for Learning Disorders. Wiley.

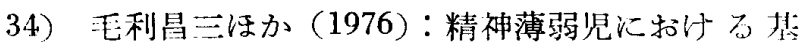
礎能力（視知覚と心理言語）と初步的兴紧（网 浯）の対応関係について 一その 1 一。网川人 兴教育学部研究集録第45号，99-110.

35) Olson, A. V. (1968): Factor Analytic Stu. dies of the Frostig Developmental Test of Visual Perception. J. Special Ed., 2, 429 433.

36) Rohracher, H. (1956) : Kleine Charakterkunde. Urban \& Schwarzenberg. 宮本忠雄: 訳 (1959)：「性格学入門」みすず書房.

37) Rosen, C. L. (1966) : An Experimental Study of Visual Perceptual Training and Reading Achievemant in First Grade. Percept. Mot. Skills, 22, 979-986.

38) Sabatino, D. A., Abott, J. C., \& Becker, J. T. (1974): What Does the Frostig DTVP measure? Exceptional Children, 40, 453-454.

39) Smith, P. A. \& Marx, R. W. (1972): Some Cautions on the Use of the Frostig Test : A Factor Analytic Study. J. Learn. Dis., 5, 357-362.

40) Thomas, J. R. \& Chissom, B. S. (1973) : Note on Factor Structure of the Frostig Developmental Test of Visual Perception. Percept. Mot. Skills, 36, 510. 


\title{
SOME ISSUES ON THE FROSTIG DEVELOPMENTAL TEST OF VISUAL PERCEPTION AND FROSTIG PROGRAM FOR THE DEVELOPMENT OF VISUAL PERCEPTION
}

\author{
JUNJI KAKUMOTO
}

(Tottori University)

The Frostig Developmental Test of Visual Perception and Frostig Progam for the Development of Visual Perception are about to be used widely in schools and clinics in Japan. However, some cautions should accompany the use of these materials, since theoretical and practical questions have been raised by American researchers.

Most questions are focussed on the indepndence of the Frostig subtests in terms of factor analytic studies. While Corah and Powell initially extracted two general factors, intelligence and developmental changes in perception, most studies reported that the Frostig five subtests measure a common perceptual function.

These findings may lead one to a serious question of the validity of the test. Yet, since the question of the subtest independence has not been resolved, one could expect $P Q$ of the test to measure the whole process of a child's visual perception.

The relationships between the test scores and the school readiness are also controversial issues. It is understandable that most research failed to find significant evidence of the relationship between them, because school achievement is made up of various psychological and educational func- tions. Thus, one should regard perceptual skill as one of the settinge necessary for school achievement. In a similar way the literature showed little evidence that perceptual training using the Frostig Program for the Development of Visual Perception had significant effects on academic improvement. In contrast to this negative evidence Halliwell and Solan demonstrated the positive effects of perceptual training on reading improvement. They attributed this success to the fact that their experiments were carried out with more instructional time, more comprehensive programs, better trained personnel, and smaller groups of students than any of the studies reporting insignificant findings.

The Frostig Test shows up a scoring problem in which a poorer raw score would receive a higher scale score and succeedingly a higher $P Q$ at a certain age level. The misuse of the conversion table standardized in the Unied States of America should be corrected by using the forthcoming Japanese standard.

The present writer concludes that although the Frostig Test is an incomplete instrument we can utilize it accompanied by other diagnostic techniques. 